\title{
Towards a global theology: Theological method and contextualisation
}

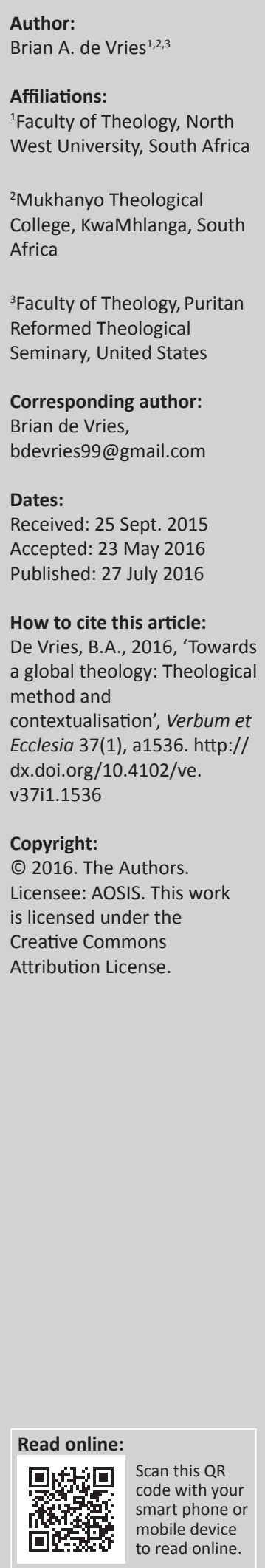

How should the cultural context influence theological formulation? This article examines contextualisation as it relates to theological method. After considering definitions and methods for formulating contextual theology, it applies the method in two areas: the missional activity of communicating the gospel in a particular cultural context, and the ecclesial activity of improving upon the theological confession of the local church. The author concludes by briefly considering the method with a global perspective.

Intradisciplinary and/or interdisciplinary implications: Some traditions have failed to contextualise the biblical message, whereas other ministry practice has radically altered its message in an attempt to be contextually sensitive. Recent research has resulted in a confusing array of conflicting methods with drastically different practical applications. This article explores how theological method largely determines contextualisation, and it offers a method that is both faithful to the biblical text and sensitive to the contextual situation.

Theologians have often grappled with a complex question: How should the cultural context influence theological formulation? (cf. Carson 1984a:11-29; Larkin 1988; Muller 1991). Though not a new question in the history of theology (Muller 1991:4), ${ }^{1}$ it has gained increasing attention. The Western Protestant missionary movement, which amplified awareness of non-Christians religions and contributed to the increase of religious and cultural pluralism, has experienced large-scale changes in the post-colonial world; ${ }^{2}$ the epistemological revolution and the pressures of globalisation are two of the major changes. ${ }^{3}$ Furthermore, the rising chorus of voices from the non-Western world, especially the new generation of indigenous theologians, is asking difficult questions about what had been accepted as unquestionable. ${ }^{4}$ These factors, and others, have forced this question into the focus of a growing number of prolegomenon studies (cf. Clark 2003; Davis 1984; Horton 2002; Lints 1993; Vanhoozer 2005). The influence of the theologian's cultural context on his or her theological formulation can no longer be ignored.

Yet some deny the influence of the theologian's cultural context: the source of revelation is God; the watchword is sola Scriptura; the method is thinking God's thoughts after him. Because all theology is reflection on Scripture and controlled by Scripture, the thinking goes, then pure theology is not affected by the cultural context. At least all the fundamental Christian doctrines and the majority of dogma remain unaffected, despite some cultural idiosyncrasies and accretions in addition to the adiophra. ${ }^{5}$ But evangelical theologians have uncovered the flaw in this thinking. ${ }^{6}$ It cannot be denied that theology - even conservative evangelical and Reformed theology - is influenced, at least to some extent, by culture. ${ }^{7}$ As Carson (1984b) notes, every truth from God comes to us in cultural guise: even the language used and the symbols adopted are cultural

1.'Rather than view the history of Western Christianity as the gradual and progressive construction of the ultimate theological system, we ought to view it as a laboratory of successful contextualization, indeed, of a series of such contextualizations' (Muller 1991:204).

2.Many have documented these changes (cf. Hiebert 1994: chapters 1-3).

3.'The pressures we face from globalization have the odd effect of making people in defined cultures think more clearly about their own contexts as the place where they "do theology". On the other hand, the perceptions that inevitably people "do theology" from within a particular culture, and that there are many, many cultures, contributes to our assumption of globalization' (Carson 1996:541-542).

4.Though his method has been questioned, William Dyrness's books are a case in point (1990, 1992, 1994), or see Wan (2003).

5.Those evangelicals most closely aligned with the fundamentalist movement have tended to view theology as transcultural or clearly neutral. ... They have assumed that the meaning of the biblical text can be readily transferred into the contemporary situation without distortion or cultural influences (Lints 1993:102).

6.Muller (1991) writes: 'In order for the gospel to become meaningful to us in our own present life-situation and to others in different places and different cultures in their distinctive life-situations, it must be brought into the diverse contexts of the modern world. It must places and different cultures in their distinctive life-situations, it must be brought into the diverse contexts of the modern world. It must using the church tradition and experience, take their stand in the reality of revelation. Though dogmaticians are bound to divine using the church tradition and experience, take their stand in the reality of revelation. Though dogmaticians are
revelation and must take seriously the confessions of the church, their work is also personal and contextual' (p. 59).

7.Those uncomfortable with this may have good motives, but their assertion - that theology is supracultural - is hard to defend. There is a better way to defend the essential unity of the faith once delivered that speaks to and judges all cultures in all times. 
expressions. No human being living in time and speaking any language can ever be entirely culture-free about anything (p. 19). ${ }^{8}$

The issue, Lints (1993:103) succinctly states, 'is focused on the degree to which culture ought to be formative in the construction of an evangelical theological framework and the appropriation of a theological vision'.

So the question is how should the cultural context influence theological formulation? This raises the complex issue of contextualisation and its many meanings, methods and models (cf. Carson 1996: chapter 14; or Hesselgrave 1994: chapters 4-5). The purpose of this article is to examine contextualisation as it relates to theological method. After considering method for formulating contextual theology, it will be applied in two areas: the missional activity of communicating the gospel in a particular cultural context, and the ecclesial activity of improving upon the theological confession of the local church. We must reject many contextual theologies and contributions to contextualisation as they clearly oppose the faith that was once for all delivered to the saints (Jude 3). Before considering this question of contextualisation, however, it is necessary to begin with a brief survey of recent discussions regarding gospel, theological formulation and culture.

\section{History of theological contextualisation}

Though not a new concept in the history of theology, 'the work of contextualization has been part of the interpretive task of the church throughout the ages' but 'this age-old exercise has been recognized, analysed, and consciously attempted only recently' (Muller 1991:202). The newness of this concept, suggests Muller, is because of several reasons: it has gone on so long that it was unnoticed; missionary efforts in the sixteenth century usually mirrored contemporary Western imperialism and colonialism; and hermeneutics did not develop in this area until more recently (Muller 1991:202-204). Yet a number of theologians and missiologists wrestled with this issue in the last century. ${ }^{9}$ Still, contextualisation is a relatively new term, one that comes with much undesirable baggage. It is therefore necessary to understand this term in historical context.

\section{Origin of the term}

The term contextualisation first appeared in a 1972 report of the Theological Education Fund titled Ministry in Context as an 'approach designed to supersede the indigenization approach that had been dominant in mission theory for over a century' (Hesselgrave 2001:294; cf. Gilliland 2000:225). The concept of indigenisation is perhaps best known for its 'threeselfs' formula of new church development: self-governing,

8.'[A]ppeal to the supracultural in Scripture is fundamentally dangerous and may lead to whimsical subjectivity' (p. 20).

9.For influential books predating the term, see Bavinck (1960); Nida (1954); Niebuhr (1951). self-propagating and self-supporting. Contextualisation gives greater attention to a fourth self: self-theologising. Contextualisation seeks to take the positive elements of indigenisation and avoid the negative elements such as colonial connotations. Contextualisation is related to other terms that grapple with similar issues: adaptation, incarnation, possession and accommodation.

The motivation behind contextualisation, as expressed by the Ecumenical Institute of the World Council of Churches director in a 1970 letter for consultation on 'Dogmatic or Contextual Theology', was to give preference to a 'contextual or experiential' theology that grows out of the contemporary historical scene and thought, in contrast to systematic or dogmatic theologies the aegis of which are discoverable in the biblical tradition and confessional statements based on the biblical text (Hesselgrave 2000:294).

Many recognise that behind this motivation was the thinking of Schleiermacher who argued that the personal subjective basis of theology is mediated in and through the community of belief, and that structures of belief in and through the life of the corporate community of faith modify individuals' conduct (cf. Carson 1987:213-257; Muller 1991:183).

After its initial use in 1972, Shoki Coe and Aharon Sapsezian developed the concept of contextualisation, arguing that emphasis must be put on theological education in context as the only way in which theology can be truly evangelistic, namely, as a living encounter of the universal gospel with the realities that people face in their own settings (Schreiner 1976:678).

From this point, contextual theology developed regionally. Presently, there is a broad spectrum of contradictory theologies, from Latin American liberation theologies (Gustavo Gutierrez), to North American (James Cone) and South African black theologies, emerging African theologies (Kwame Bediako), varieties of Asian theology, and even to Feminist and white male Anglo-Saxon theologies. The essential criterion of contextual theology is the extent to which its understanding of the gospel leads people to Christ (Schreiner 1976:679). But this begs the question: who defines gospel and Christ, or theology, theological method and mission?

It is important to note that from its origin, the term contextualisation was directly related to the practice of missions. As Hesselgrave (2000) explains, Shoki Coe and others have advocated it:
as a new way of theologizing which takes into account the dialectic between contextuality and contextualization. The aegis of theologizing has been located in praxis within the world rather than in the exegesis of Scripture. And mission has become a matter of discerning what God is doing in the contemporary world and participating in a missionary task delineated in the NT. (p. 294)

Also from its origin, conservative scholars have responded to the liberal definition of contextualisation and the underlying theological method. 


\section{The evangelical response}

The International Congress on World Evangelisation in 1974 at Lausanne, Switzerland gave the term some attention, as did the Lausanne Consultation on Gospel and Culture in 1978, which produced the Willowbank Report and published a number of related papers (Stott \& Coote 1980). David Hesselgrave (2001) states that though there are some who find the new term ambiguous and misleading, ${ }^{10}$ most evangelicals 'take the approach of redefining the word and redirecting the method' ${ }^{11}$ In the decade following Willowbank, many evangelicals have developed various nuances in the evangelical understanding and application of contextualisation.

As with the definitions of liberal theologians, it ultimately comes to a question of hermeneutics and theological method. Lints outlines the two extremes of most evangelical discussions: the first 'starts from the assumption that the revelatory trajectory moves only from authoritative Word into contemporary culture'; the other extreme 'starts with the assumption that the trajectory moves both from text to context and from context to text' and 'suggests that the meaning of the biblical message is actually determined by the constraints of the contemporary' (Lints 1993:102). ${ }^{12}$ The critical dispute is largely 'focused on the degree to which culture ought to be formative in the construction of an evangelical theological framework and the appropriation of a theological vision' (Lints 1993:103).

Carson (1996:540) recognises that contextualisation 'takes the indigenous principle one step further'; churches 'should think through their theology in their own context'. He (Carson 1996) also notes two extremes in definition and method, helpfully describing the former:

The first recognizes the once-for-all truthfulness and authority of God's self-disclosure in Scripture, but then also frankly recognizes that all attempts to interpret that Scripture are cultureladen efforts undertaken by sinners (redeemed or otherwise), and therefore subject to more or less distortion. It is not so arrogant as to think that all biblical and theological reflection has been accurately and exhaustively accomplished by one group of Christians (ours!), and therefore that the only task remaining is to translate and promulgate the results for the sake of others. It fully appreciates how contextualization, properly defined, is the logical extension of indigenization. (p. 540)

But this definition also leaves the questions of method and degree unanswered.

\footnotetext{
10.'Indigenization' is still a better term than 'contextualization', since it is easier to purge 'indigenization' of its connotations of colonialism than to purge 'contextualization' of its original denotation and (mis)use by liberal theology. But evangelicals have given new definitions to contextualisation and have generally accepted it to describe the manner in which the biblical message is shaped in and by a given culture. So given the general acceptance and present use of the term contextualisation by evangelicals, it is perhaps best to always be aware of the misuse of contextualisation and then make conscious efforts to reinterpret and constantly guard it. Paul Hiebert and others have done this with a qualifying adjective: 'critical contextualization'.

11. Hesselgrave (2001) notes that evangelicals generally differ: 'in such matters as the importance to be attached to cultures; the relation between evangelism and importance to be attached to cultures; the relation between evangelism and faith and theologizing, meaning and symbol, form and function, and meaning and relevance' (p. 295).

12.See also Nicholls (1979:24ff.); Stott and Coote (1980:50).
}

What is the state of the present evangelical discussion of contextualisation? No consensus has been reached on a precise definition, though in the last two decades it has come to represent an assortment of methods and models for the integration of gospel and culture. Dean Gilliland (2000) suggests that the various nuanced definitions share the goal of communicating the gospel to every people group; therefore the worldview of that people provides a framework for communication, the questions and needs of that people are a guide to the emphasis of the message, and the cultural gifts of that people become the medium of expression (Gilliland 2000:225). ${ }^{13}$

More recently, several evangelicals have given the contextual situation greater attention. Stanley Grenz and Franke (2001:150-166), describing themselves as postconservative non-foundational evangelicals, critique both the liberal methods of correlation and evangelical and liberal methods of contextualisation, arguing instead for 'an interactive process that is both correlative and contextual' - 'an ongoing conversation between "gospel" and "culture"'. ${ }^{14}$ But many have conclusively shown the error of this proposal. ${ }^{15}$ Though it may be successful in uniting neo-orthodox evangelicals and neo-liberals, it will likely only sow the seeds for a new generation of thinkers to theologise under some stripe of the widespread liberal flag. The answer for Bible scholars who desire to be righteous does not lie in further destroying the crumbling foundations ${ }^{16}$ or even in rebuilding the foundations that have been destroyed. ${ }^{17}$ The answer is always to take refuge in the immovable YHWH who sits supremely above culture and whose Word upholds and judges the world (Psalm 11). ${ }^{18}$

\section{Models, methods and meanings}

Conservative evangelicals should continue to move cautiously forward in this area as they develop a theological method true to the Reformation principle sola Scriptura, while recognising the influence of cultural contexts. Before considering this project in the next two sections, it is necessary to review several post-1972 models and methods, and define several complex concepts.

13. However, Hesselgrave (2000:295) observes that "recently the field has "settled" and no really significant development has taken place' and that 'more has been done in hermeneutics than contextualization'.

14.Grenz and Franke (2001) state: 'Unlike either correlation or contextualization, this model presupposes neither gospel nor culture - much less both gospel and culture - as preexisting, given realities that subsequently enter into conversation. culture - as preexisting, given realities that subsequently enter into conversation.
Rather, in the interactive process both gospel (that is, our understanding of the Rather, in the interactive process both gospel (that is, our understanding of the
gospel) and culture (that is, our portrayal of the meaning structure, shared sense of personal identity, and socially constructed world in which we see ourselves living and ministering) are dynamic realities that inform and are informed by the conversation itself (p. 158)'.

15.For example see Wellum (2004:161-97).

16.Wisdom states that ancient landmarks must be treated with respect $(\operatorname{Pr} 22: 28)$. Disregarding, reinterpreting, or rewriting history - especially the church's theological development - is a dangerous activity inviting heresy.

17. Brian Ingraffia (1995) has convincingly shown that Christian theology is not built of the foundations of modern philosophy (ontotheology), but on Scripture.

18.The arguments presented here reflect Niebuhr's analysis of the debate and differentiation into: Christ in culture, Christ against culture and Christ above culture. See Niebuhr (1951) as well as Carson (2008). 
A number of models offer ways to 'do contextualisation'; three books have received the most attention. In 1985, Roman Catholic Robert Schreiter offered various approaches for how Scripture relates to cultural contexts thorough study of culture, theology and other approaches. In 1989, evangelicals David Hesselgrave and Edward Rommen reviewed contextual theologies from around the world, then provided several frameworks for analysis. Roman Catholic Stephen Bevans published his works that review various models of contextualisation in 1985 and 1992. Evangelical Gilliland (2000:227) reviewed some of these models, describing each starting point and focus. ${ }^{19}$

From a discussion of various models for contextualisation, the focus gradually shifted to the epistemology, hermeneutics (cf. Wan 2004) and theological method behind the models (cf. Hesselgrave 1984:691-738). This discussion is even more complex; considering two evangelical contributions. In 1988 William Larkin published a study of hermeneutics and culture, examining the situation from historical, nonevangelical, evangelical and missiological perspectives. ${ }^{20}$ Likewise, Hiebert (1994) has explained what he calls critical contextualisation $^{21}$ - an approach beginning with cultural exegesis as a way of developing applications that are faithful to both the local culture and Scripture. Both of these approaches offer cautious biblical advice for contextualisation..$^{22}$

These models and methods have spawned a whole literature on communicating the gospel in specific cultural settings, including popular-level contributions like the articles of Phil Parshall, David Racey, John Travis, Ralph Winter and Dudley Woodberry's Muslim contextualisation spectrum, pragmatic methods like the Camel Method (Greeson n.d.), serious scholarship like Kenneth Cragg's (1985); and the development of a North American ecclesiology by the Gospel and Our Culture Series following Lesslie Newbigin (Guder 1998 2000; Hunsberger \& VanGelder 1996). More recently, A. Scott Moreau (2006c) has argued for a comprehensive contextualisation that moves beyond theologising, seeking to contextualise all dimensions of religion. ${ }^{23}$

Contextualisation has become an exceedingly complex concept that is difficult to define comprehensively. But

19.The seven models he analyses range from the adaptation model, which makes biblical concepts fit into each cultural situation to the critical model, which analyses biblical concepts fit int

20.Further studies of this caliber are greatly needed.

21.The fullest explanation is in Hiebert (1994:chapters 4-5). Other works include Hiebert $(1973,1987,1996)$.

22.See also the conversation in 1960 between two Roman Catholic theologians, Tharcisse Tshibangu and Alfred Vanneste, who debated the merits of developin an African theology (Bevans 2009:314). Since then there have been many other voices in the global conversation including Healey and Sybertz (1996) and voices in the global conversation, including Healey and Sybertz (1996) and (2012) (2005a, 2005b).

23.Moreau explains seven characteristics of his comprehensive contextualisation (a mediating position incorporating both 'translation' [i.e. propositional] models
and 'existential' models) and then seeks to apply it to the seven dimensions of and 'existential' models) and then seeks to apply it to the seven
religions as adapted from secular religious scholar Ninian Smart. consider these simple definitions of culture, theology and contextualisation. Newbigin (1986) argues:

By the word culture we have to understand the sum total of ways of living developed by a group of human beings and handed on from generation to generation. Central to culture is language. The language of a people provides the means by which they express their way of perceiving things and of coping with them .... . And one must also include in culture, and as fundamental to any culture, a set of beliefs, experiences, and practices that seek to grasp and express the ultimate nature of things, that which gives shape and meaning to life, that which claims final loyalty. I am speaking, obviously, about religion. (p. 3)

Though not comprehensive, Newbigin's definition is helpful because it captures the essence of culture and the vital association of culture and religion. ${ }^{24}$

Lints (1993) gives a provisional definition for theology:

Theology involves not just the study of God (the theistic matrix) but also the influence of that study on the rest of one's life. It is possible to distinguish these two levels, but they are never separable in practice. (p. 19)

This captures the essence of theology in a manner similar to Calvin's (1960:37, 1.1.2): 'it is certain that man never achieves a clear knowledge of himself unless he has first looked upon God's face, and then descends from contemplating him to scrutinize himself ${ }^{\prime} \cdot{ }^{25}$

Finally, for the following discussion, contextualisation is 'the manner in which the expression of the biblical message is shaped in and by the native conceptuality of a given culture' (Lints 1993:101). The contextualisation of theology 'is both an objective and a subjective, both a corporate and an individual exercise' (Muller 1991:210); it is the continual process by which Christians in every cultural context formulate and apply God's word.

\section{Theological method and contextualisation}

This definition of theology is provisional at best, considering how contextual theology should be formulated. Indeed, the definition of theology often determines and is determined by the theological method used in the process. So what is theology, and how should theological method interface with culture? (cf. Carson 1984; Clark 2003; Lints 1993; Vanhoozer 2005).

\section{The process of theologising in context}

Perhaps in describing this process, it is easiest to start by stating what it is not. Kevin Vanhoozer (2005:311-313) explains, (1) It is not a form of cultural relativism - 'it does 24.For more on this significant relationship, see VanTil (1959).

25.Lints (1993:65-66) adds: 'the evangelical theological vision begins with God's revelation ... As we come to understand the revelation, we come to understand
ourselves anew. And the more we understand ourselves, the more we will ourselves anew. And the more
understand the revelation of God'. 
not consider the gap between past and present, canonical text and cultural context, so great that we cannot make meaningful connections between them', (2) It is not a form of cultural determinism - it does not view context as 'the quasi-causal explanation for why things happen as they do' and theology as 'a mere function or surface phenomenon of cultural and social and political "depth structures," where all the real action is thought to lie'. (3) Nor is contextual theology a form of cultural absolutism - it is neither biblicist, in viewing Scripture as supracultural, acultural, or a timeless culture, nor is it correlationist, by letting 'the concerns and questions of the present culture set the theological agenda'. And (4) it is not a form of cultural colonialism - it does not impose a specific cultural understanding of the faith upon the people of a different culture.

Contextual theology, then, 'is the attempt, as bold as it is humble, to understand and perform the theo-drama in terms of a particular context'; it is accountable to both the canonical texts and the contemporary cultural situation (Vanhoozer 2005:314). The real question, however, is how the canon and culture interface. The crux of the matter lies in how the relationship and interaction of these two horizons is conceived. In every context, the theologian's goal is to worship God - to hear and obey him who speaks and acts. To worship with as few distortions as possible requires a clear distinction between the horizons of the biblical text and the experience of the interpreter. Lints (1993) states:

The better we understand who we are as interpreters, the better we will be able to understand the speech of God in its original context. The better we understand the speech of God in its original context, the better we will be able to understand our own distorting influences. (p. 65)

Yet theology is not complete with clear definitions of canon and culture. Scripture is not acultural or supracultura; the Bible is God's word of transcultural truth that addresses every culture and yet was revealed in cultural particulars of time and place (cf. Carson 1984b:19-20, 1987:249; Vanhoozer 2005:314). David Wells (1985) states that the task of theology is to discover what God has said in and through Scripture and to clothe that in a conceptuality which is native to our own age. Scripture ... needs to be de-contextualised in order to grasp its transcultural content, and it needs to be recontextualised in order that its content may be meshed with the cognitive assumptions of our own time (Wells 1985:177).

This process of 'recontextualisation' is the task of systematic theology, more particularly of missiology - communicating the gospel in cultural context and living the gospel in the world while not of the world. This also requires 'exegeting' the context. But contrary to liberal and postconservative methods, ${ }^{26}$ the starting point is divine revelation and the revelatory process is one way, according to Lints (1993):

26.Grenz and Franke (2001:88) write: 'the theological reading of the text always moves from, and rurns to, the contemporary situation in which the faith moves from, and returns to, the contemporary situation in which the faith community is living, even the exegetical methods. We read the text so that the Spirit might nurture us in the ongoing process of living as the contemporary embodiment of the paradigmatic narrative of scripture'.
Divine revelation does not occur in the interaction between the Bible and my experience within culture. The meaning of revelation can be ascertained with the aid of the conversation that takes place between the Bible and my experience within a particular culture, but it is the biblical revelation that possesses the unique authority to challenge and transform my culturalbound experience. The revelatory trajectory does not move from text to context and back again to the text. Neither does the interpreter stand at the midpoint of this interchange determining what God's word for our time actually is. The cognitive horizon of the interpreter must be prescribed and thereby challenged by the meaning of the biblical revelation. (p. 115)

Furthermore, the task cannot simply be a translation of the biblical text into culture-specific language (cf. Kraft 2005; Nida 1964). Rather, God's revelation must be allowed to transform the interpreter and the interpreter's context. ${ }^{27}$ Contextualisation includes not only the translation of Scripture into symbols selected from the local context, but also the confrontation and transformation of culture, rejecting or recycling corrupted symbols. As Lesslie Newbigin (1986:64) states: 'The missionary encounter of the gospel with the modern world will, like every true missionary encounter, call for radical conversion'. Bruce Nicholls (1978) notes:

The gospel judges all of culture and not just some of it, destroying what is contrary to the Word of God and recreating what is true to God's universal revelation to mankind. (p. 62) ${ }^{28}$

Although these theologians clearly deny the validity of a 'revelatory circle' (or uncritical definitions of the hermeneutical circle), they do not deny the validity of a hermeneutical spiral.

\section{The particulars of contextualisation}

Before considering this hermeneutical spiral, however, two other particulars of the contextualisation process must be considered to define the influence of the cultural context on theological formulation. The first is the undeniable presence of preunderstandings, or presuppositions. David Clark (2003) observes two possible mistakes here:

One is to pretend that all cultural or philosophical preunderstanding does not exist or is relatively unimportant. ... The other is to so delight in cultural and philosophical assumptions that they set in concrete the entire agenda for theology. (p. 110) (Cf. also Hesselgrave 1999:159ff.)

Defining this preunderstanding makes all the difference..$^{29}$ For some, preunderstandings are simple mental baggage that

27.Lints (1993:135) concludes, 'We must seek to ensure that cultural expressions in the theological framework always remain open to correction by the Scriptures themselves. The framework of the Scriptures must take precedence over the cultural expressions of that framework'.

28.Nicholls (1978) argues that the evangelical: 'begins with the process of contextualization with the unique and final revelation of God in Christ and the gospel which he interprets in the context of his own and the receiver's culture. To do this in a relevant way he must understand the cultural context and the questions which it raises. He must study both the Bible and the newspaper. But the process of theologizing is a one-way street (p. 62)'.

29.Carson (1984b:12-13) argues that if this term means 'the mental baggage, the "functional non-negotiables" that one brings to the text, Christians will happily recognise the problem and learn a little humility in their exegesis'; but if it means 'something like "immutable non-negotiables", a function of an entire world view at "something like "immutable non-negotiables", a function of an entire world view at "pdds with Scripture, then Scriptu' 
distracts exegesis; for others they are an extra-biblical framework imposed upon Scripture. ${ }^{30}$

To confuse these two uses of preunderstanding, says Carson (1984b):

is to devastate both theology and epistemology. The one use helps us to be more careful, encourages us to follow the 'hermeneutical spiral' to bring our horizon of understanding into line with the horizon of understanding of the original author, and ultimately brings our mind into increasing proximity with what the text actually says; but the second becomes a reason for transmuting the text into something else. (p. 13)

Recognising the presence of these preunderstandings and guarding how they affect theology is vital for contextualisation. Indeed, part of the process of minimising distortion in theological formulation is the transformation of preunderstandings - the activity of the ongoing contextualisation of an ecclesial community as discussed below.

The second particular of contextualisation is the principle of sola Scriptura. Conn (1983:13-14) recognises that Calvin's theological method 'of sola Scriptura was not simply the demand that we approach the Bible with a tabula rasa'. Although the Reformation reaffirmed Scripture as the only final authority and inspired, infallible source of revelation, it did not deny that the Holy Spirit can also influence sanctified wisdom with other secondary sources. As Cortez (2005b:358) notes, 'sola Scriptura does not necessitate that Scripture is the only source for theology any more than it must mean that it is the only source of authority for evangelicals'. ${ }^{31}$ Contextual influences - contributions from tradition, reason and the social sciences - together with preunderstandings, can and should influence theological formulation. Yet Scripture must remain the final source and authority for theology. William Larkin (1988) concludes:

It is possible for the Scriptures to serve also as a casebook, a platform for further elaboration, or as an occasion for the ongoing dynamic of truth seeking. There is place for such interpretive options as long as they remain subsidiary to the primary function of Scripture as the standard of reference. (p. 284; cf. Lints 1993:291)

Thirdly, there is the progression of the hermeneutical spiral. J.I. Packer's description (1983) of the theological method explains the underlying assumptions of this aspect of contextualisation:

Now the evangelical theologian's method of seeking understanding is this: First, he goes to the text of Scripture to learn from it the doctrine of Scripture just as he goes to the text of Scripture to learn from it the doctrine of everything else it deals with. At this stage he takes with him as his presupposition,

30.Nicholls (1979:40ff.) describes three factors that affect an interpreter's preunderstandings: ideological factors - 'reflecting the interpreter's world view and system of values'; cultural factors - reflecting 'the influence of the institutions and customs of society'; and the supra-cultural factor - 'which is either conversion to Christ' or 'rejection of Christ'.

31.Most recognise that there are many other legitimate sources of authority for the believer, all standing under Scripture's ultimate authority. Similarly, the Bible can be understood as the primary source for theology in such a way that it stands over other sources of theology, but not alone. provisionally held...By the light of his preunderstanding he discerns in Scripture material that yields an integrated account of the nature, place, and use of the Bible. From this doctrine of the Bible and its authority he next derives by theological analysis a set of hermeneutical principles; and armed with these, he returns to the biblical text, to expound and apply its teaching on everything more scientifically than he could do before. It at any stage what appears to emerge from the texts appears to challenge his personal preunderstanding and/or call in question the tradition that was his personal springboard, he lets dialogue between the appearances develop, with the purpose of bringing his present understanding fully into line with biblical teaching once he sees clearly what this is. Thus he moves to and fro within the hermeneutical spiral. (pp. 348-349)

Thus, it is possible to:

fuse the horizon of understanding of the interpreter with the horizon of understanding of the text so that true communication across the ages or from text to interpreter is possible. (Carson 1984b:16) (see also Gadamer 1976)

In this process, writes Lints (1993:115), 'we discover the meaning of the text as we come to understand our own cultural predispositions and the impact that these have on our interpretation of the Scriptures', and since 'the biblical text is an ancient text written out of cultures quite different from our own', it is crucial to understand 'not only modern culture but also the culture in which the original revelation occurred'.

\section{The problem of evil in the world}

Thus, God's revelation is to be heard and obeyed in each particular cultural context while the hermeneutical spiral works to refine this theology and filter out any unbiblical accretions from preunderstandings and contextual influences in obedience to God ( $\operatorname{Rm} 1: 5,16: 26)$. David Clark (2003) gives a helpful summary of the evangelical stance towards culture in theological formulation:

(1) We should recognize the reality of cultural influence on all theological interpretation. (2) We must purposefully adopt a selfcritical stance toward any and all cultures. (3) Yet we should assert the need for theology to achieve cultural relevance. And (4) while doing so, we must yield to the priority of Scripture over any and all cultural assumptions. (p. 110)

There is a tendency in much of the literature, however, to be enamoured with the good in culture to the point of engaging in uncritical dialogue, neglecting the vital need for 'a selfcritical stance towards any and all cultures'. All theology is contextual in that it is expressed in and for a specific context; yet this does not mean that theology or contextualisation seek to be 'conformed' to this world ( $R m$ 12:2). Contextualisation is also required to be counter-cultural, to stand over and against sin in a particular cultural context and allow Scripture to judge it:

The gospel judges all of culture and not just some of it, destroying what is contrary to the Word of God and recreating what is true to God's universal revelation to mankind. (Nicholls 1979:62; cf. Vanhoozer 2005:357) 
Contextualisation cannot ignore the problem of the evil in culture. Conn (1997) has recognised this as one of the major flaws of the apologists and fathers of the early church, and it has since echoed through history:

Sin's side effects could be treated in an emergency room on an out-patient basis. There was no need for intensive care units. Culture was good 'and not an evil', commented Origin. ... Sin was the result of ignorance, not an inherited evil nature, argued Justin. ... Given these perspectives, accommodation became an easier way to deal with the cultural agenda issue than antithesis. (p. 99)

With this theological method, suggests Conn (1997:100), 'comes a confusion of the Bible as norm with theology as a neutral search for the rationally ideal'. Grenz and Franke's (2001:58ff.) proposal - 'the biblical message is theology's norming norm' - just echoes this ancient error. ${ }^{32}$

Consider how evil in culture affects both the ongoing conversion of the interpreter and the ongoing transformation of culture. Regarding the first, Lints (1993) writes:

The theologian's hope lies not in an ability to remove our cultural blinders so that we might see God but in the power of God to break through our cultural blinders and thereby enable us to see ourselves more clearly by the radiance of his glory. Strategically, this begins with conversion, but it continues most forcefully as we immerse ourselves in God's story, as we begin to think in the categories of God's revelation. This process reaches fruition when we adopt a prophetic stance within our culture. This entails understanding our culture and speaking to it in a language that is both intelligent to it and critical of it, a process that is bound to be painful, for it will inevitably remind us of our own depravity. (p. 106) ${ }^{33}$

This 'prophetic stance' is the theologian's task in the ongoing transformation of culture. Andrew Walls (1996:7-9) has described this task as the indigenisation principle (the push to become more contextualised) and the pilgrim principle (the pull towards unity of the global church). But Sherwood Lingenfelter (1998:19ff.) goes even further, describing culture, not as a neutral environment or mix of good and evil, but as contaminated by and in captivity to sin. He uses three metaphors: the prison of culture from which the gospel liberates sinners, the pilgrim believers traveling through this world and the transformation of culture that believers enact. His metaphors deal more effectively with the problem of evil and are closer to the biblical depiction of culture as controlled by sinful powers and corrupted systems (cf. Eph 2:1-3, John's use of cosmos in Jn 15:19 and 1 Jn 2:15). ${ }^{34}$

32.'Whatever speaking that occurs through other media does not come as a speaking against the text. To pit the Spirit's voice in culture against the Spirit speaking through scripture would be to fall prey to the foundationalist trap' (Grenz \& Franke 2001:162)

33.Lints (1993) states: 'Modern hermeneutical theory moves in just the opposite direction. Proponents of such theory argue that because we stand within the "language game" of a postindustrial modern society, we are captive to the workin assumptions of that culture and are unable to assume a "precritical" stance in relationship to the culture and are unable to assume a "precritical stance in modern culture stands prophetically against the divine revelation rather than the other way around' (p. 106n).

34. Hiebert speaks of critical contextualisation, reflecting the need for discernment and as a parallel term to the critical realism for which he often argues; other qualifying adjectives like apostolic (Hesselgrave) and covenantal (Conn) bette

\section{Doing theology in cultural context}

Having considered the method of formulating contextual theology, it is now possible to reflect on how to 'do' it. There are two major areas of application: the missional activity of communicating the gospel in a particular cultural context, and the ecclesial activity of improving upon the theological confession of the local covenant community. The reason for treating these areas separately is complex and demands explanation.

Contextual theology first developed as an alternative to the systematic and dogmatic theologies influenced by modern Western philosophies (Hesselgrave 2000:294). ${ }^{35}$ More recently, the focus has shifted from models of application to epistemology, hermeneutics and theological method - most scholars now recognise that all theology is contextual to some degree. Cultural context cannot be ignored. Yet, a distinction must be made between the formulation-application in a missional context and the formulation-application in the ongoing theologising activity of an established church. ${ }^{36}$ Contrary to Tiénou and Hiebert (2006:219-238), ${ }^{37}$ the method of both theology and missiology must be the same. The difference lies not in the process or authority, but in the context within which it is applied.

Bruce Nicholls (1979) astutely notes that much of the misunderstanding of contextualisation has arisen through a failure to distinguish the two-way process of contextualising the Word in a specific cultural situation and the exegetical task of comprehending biblical or dogmatic theology as an authoritative base from which to contextualise (Nicholls 1979:50).

He is reflecting on the difference between the one-way process of the revelatory trajectory and the two-way process of the hermeneutical spiral (cf. Lints 1993:115; Nicholls 1979:62). Yet Nicholls also appears to be observing what has more recently been called the third horizon of contextualisation in a missional setting.

(footnote 34 continues...)

guard this term. Prophetic or even elenctic contextualisation is also an option since it captures the idea that the motivation of contextualisation is to live and communicate the Word more clearly.

35.This sentiment is largely held by non-evangelicals, though it exists to a lesser degree in some evangelical literature; evangelicals Paul Hiebert and Tite Tiénou seem critical of systematic theology in their essay 'Missions and the Doing of Theology' (2002:85-96).

36.It should also be noted that Lints helpfully recognises the different levels at which human reason operates in this process and distinguishes 'the dual nature of rutionan 'native 'native rationaly serves alloundational (lints 1993:132-135). He also makes a external reason is culturally conditioned (Lints 1993:132-135). He also makes distinction between theological framework and theological vision: 'A theological framework remains constant over time, while a theological vision properly change as culture changes' (Lints 1993:262ff.). Lints (1993) further states: '[T] he fact that this framework is properly subject to reform should in no way be taken to imply that the Scriptures themselves contain data that may be organized in any number of conflicting fashions or indeed that there are a variety of competing frameworks in the Scriptures themselves' (p. 288).

37.This article is the reconfigured and expanded version of an earlier essay, 'Missions and the doing of theology'. Hiebert and Tiénou treat systematic, biblical, and missional theologies as 'complimentary' methodologies, similar to the different scientific reorch biblical text While this description is helpful in highlighting their differences, it fais biblical text. While this description is helpful in highlighting their differences, it fails to account for the logical dependencies of missiology on systematic theology, systematic theology on biblical theology, and of the and hermeneutics. Hiebert claims to maintain sola Scriptura while arguing that missional theology must start with phenomenology before integrating this with ontology and missiology. 
This concept of the third horizon was popularised by Daniel von Allmen's article (1975:37-52) on the birth of theology in response to what he saw were weaknesses in Byang Kato's African theology (cf. Gadamer 1976; Thiselton 1980). Carson has soundly refuted the errors in von Allmen's thinking, yet many of these errors continue, even among evangelicals. Carson (1987) explains:

The first horizon is that of the biblical documents or, as some would have it, of the first generation of Christian believers as that perspective is preserved in the New Testament. The second horizon is ours - i.e. that of established Christians who seek to understand the Scriptures. ... Contemporary discussion of mission, however, goes a step farther and deals with the 'third horizon' - viz., the horizon of understanding of the group or people being evangelized. (p. 218)

Though the same theological methodology is used, the ecclesial activity of improving upon the theological confession of a local church involves only two horizons whereas the missional activity of communicating the gospel in a particular cultural context demands three.

\section{Missional theologising in cultural context}

From Acts 15 on, discussion about contextualisation has been motivated by missionary concerns. The vast body of literature on the issue continues to expand. ${ }^{38}$ There are various positions within North American evangelical missiology regarding contextualisation: some appear to follow Charles Kraft (1996) from the Fuller school, ${ }^{39}$ some Hesselgrave and Hiebert from the Trinity school, and others appear to be in the middle, on the edges, or uncommitted..$^{40}$ Consider missional theologising and its process, methods and problems.

\section{Process of Missional Theologising}

The missionary task is far more complex than people often realise. ${ }^{41}$ There are major challenges to understanding the gospel as one attempts to bridge the gap between the interpreter's horizon in his contemporary situation and the Scripture's horizon in their ancient setting. But as Carson observes, the missionary has even greater challenges as he tries to 'cross from the second horizon to the third' and teach biblical content to other people:

Indeed, the greater the cultural gap between the evangelizing church and the target people (or, otherwise put, between the second and the third horizon), the greater the potential for massive distortion of the message. (Carson 1987:218)

38.A. Scott Moreau's bibliography (2006a) lists more than 2000 publications in the last three decades. See also Moreau (2012).

39. Kraft developed the dynamic-equivalence and communication theories.

40.This generalisation does not account for all nuances. For examples similar to Kraft's position, see Taber (1979), or VanEngen (1994). For examples similar to Hesselgrave and Hiebert, see Lingenfelter (1998); Carson (1996); or Fleming (1980). For examples of others who do not fit this classification, see Conn (1984) or Moreau (2006b).

41.It is tragic that a division is often made between theology and missiology; it accounts for many pathetic practices in recent missions, and perhaps some oversights of traditional theology.
The theological method explained above should be used in missional theologising, yet attention must be given to challenges created by the third horizon and preunderstandings.

The third horizon adds a second, separate dimension to the hermeneutical process. ${ }^{42}$ Carson (1984b) states that the missionary must attempt to fuse his own horizon of understanding with the horizon of understanding of the text; and having done that, he must attempt to bridge the gap between his own horizon of understanding, as it has been informed and instructed by the text, and the horizon of understanding of the person or people to whom he ministers (Carson 1984b:17).

It cannot be affirmed that the Bible contains supracultural truths - principles that can be translated into a new culture. This approach leads to positing a canon within the canon (Carson 1987:249). Rather, the missionary must work to build a hermeneutical bridge between the two cultures (cf. Hiebert 1994:89) ${ }^{43}$ - an activity requiring considerable effort and 'exegesis of the culture'.

Furthermore, it may seem that preunderstanding is a much easier challenge in missional contexts because the audience ${ }^{44}$ has little or no previous knowledge of Christian theology. But in actuality, preunderstanding is a major issue in all missional contexts because the communicator often has little understanding of the audience's culture. The audience also has their own extensive preunderstanding of 'theology', whether from unbiblical sources, or from general or special revelation. Most of the world has already heard about Jesus, and has either rejected the biblical truth or, more commonly, has learned an adulterated notion of the truth. Additionally, all people are religious, but most people are not Christians. Therefore, missional contextualisation with the hermeneutical spiral must seek to overcome these preunderstandings, not only in a way that accurately conveys gospel truth but that also allows the Holy Spirit to convict sinners of cultural, worldview and spiritual sin.

\section{Methods for Missional Theologising}

This is a task so staggering that many missionaries have not dared to begin, attempting 'to just preach the gospel' but, in actuality, also preaching the principles of their own culture. The gospel must be contextualised in dependence on the Holy Spirit for guidance and sanctified wisdom - there is no other option for intercultural missions or for gospel communication in a world of increasing religious pluralism. At least two helpful methods have been developed to aid this process. ${ }^{45}$

42.It is very important to note that this hermeneutical bridge is built by exegesis of the sinful cultures involved, and therefore differs from the hermeneutics of inspired, infallible Scripture.

43.'The leader must also have a metacultural framework that enables him or her to translate the biblical message into the cognitive, affective, and evaluative dimensions of another culture' (Hiebert 1994:89).

44.Despite the term audience, communication between speaker and listeners is not one-way.

45.Bavinck's Possessio model (the idea of taking possession of and transforming culture) is less known but superior in many ways for its holistic approach. A hybrid 
Hiebert (1994:88-90) has developed what he calls critical contextualisation. There are four steps in this process, (1) exegesis of the culture through phenomenological analysis, (2) exegesis of the Scriptures related to the question at hand, (3) critical evaluation of the cultural concept in light of Scripture with a decision on how to respond and (4) application of the new contextualised concept that expresses the Christian meaning. ${ }^{46}$ Underlying Hiebert's method is his sign theory which argues that meaning is 'in the correspondence between the inner idea or image and the outer reality' (i.e. critical realism), rather than, as Kraft first taught, in just the outer idea (Hesselgrave 1994:75-80).

William Larkin (1988) has analysed the necessary elements of a hermeneutical bridge:

human language, which can communicate meaning across time and culture; a faithful God, who speaks eternal and universal truth and illumines by his Spirit; an inspired and fully authoritative Scripture, which purposes to instruct humankind in all generations and cultures; humankind, whose unity is more basic than its cultural diversity; and a historical framework, which sees all humankind since Christ living in the last days. (p. 304)

Larkin's model is similar to Hiebert's, though he enters the hermeneutical spiral at the point of Scripture and gives proper attention to the problem of sin: (1) start with a biblical preunderstanding; (2) study initially the text in context; (3) study the cultural preunderstandings; (4) locate the normative biblical content; (5) identify the contemporary situation; and (6) develop the response (summarised in Moreau 2006b).

\section{Problems in Missional Theologising}

In addition to the challenges of the third horizon and preunderstandings, several other problems may arise in missional theologising. The list of these includes misunderstanding of culture, misinterpretation of Scripture, miscommunication and misapplication of Scripture. ${ }^{47}$ Ethnocentrism, the belief that one's own people group or cultural ways are superior to others, was a problem in the past. Colonial missions of past centuries often sought to civilise the pagans by preaching Western culture as well as Christ. In theologising, this error is committed by treating any theology that has developed in a missional context as suspect or inferior ${ }^{48}$ or by assuming that theology is complete and non-Western churches must only accept the results (cf. Conn 1983:17). Ethnocentrism, however, should not be

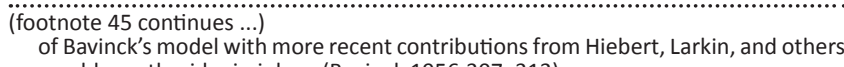

of Bavinck's model with more recent contributions from Hiebert, Larkin, and others would greatly aid missiology (Bavinck 1956:307-313).

46. By starting with culture, Hiebert attempts to overcome customary oversights and a failure to apply before understanding. Though a necessary reminder (in practice the hermeneutical spiral may be entered at any point), this starting point may distort the outcome of this process or become unfaithful to the principle of sola Scriptura.

47.Each of these listed involve communication theory, while the list of problems covered below deal with cultural forms. This reflects how the process of contextualisation gradually transitions from gospel communication to gospel contextualisation gradually transitic

48.An example of this is theology about demons and the spirit world. Many contemporary contributions are suspect, and there is slow acceptance of sound biblical treatments in missions. See John L. Nevius (1892). confused with a critical assessment that recognises one culture as more aligned with biblical truth than another.

Another problem is uncritical accommodation. Also a historical error, it has more recently been used to describe the uncritical acceptance of a culture's unbiblical or sinful assumptions, values and practices. In theologising, this error is committed when theology is shaped by 'the needs, beliefs, and values of the present context' or when 'the concerns and questions of the present culture set the theological agenda' (Vanhoozer 2005:312). Many contemporary missionary practices are dangerously close to or guilty of this error.

\section{Ecclesial theologising in cultural context}

Ecclesial theologising is the indigenised church's increasingly mature reflection on and conscious living out of Scripture. The major distinction of ecclesial contextualising from missional contextualising is related to its two, not three, horizons of understanding and its radically changed preunderstandings. Literature produced in this area is not often clearly distinguished from the missional context. ${ }^{49}$ Consider the process, problems and protections of ecclesial theologising.

\section{Process of Ecclesial Theologising}

As explained above, the discussion of the new term contextualisation was initiated by attention to the fourth self self-theologising - in church planting. Not only is a mature church self-governing, self-propagating and self-supporting, but it is also self-theologising. The covenant community and priesthood of all believers aid this form of contextualisation. Lints (1994) argues that if:

the faith is not defended anew in the face of the difficulties that arise in each new cultural setting, it will die. It cannot simply remain parasitic on the faith of generations past. (p. 86) ${ }^{50}$

However, it should not be assumed this means developing new theology. Because the foundation and authority of the truth remains the same and because the same Spirit guides the process, the result, if faithfully performed, should yield a complementary expression in culturally acceptable terms of the same Bible truth. This process continually reforms preunderstandings, and the hermeneutical spiral moves the local church closer to knowing and living biblical truth. As Carson (1987) writes:

If by African, Scottish, Indian and Burmese theologies we are referring to attempts by nationals to work directly from Scripture in order to construct a biblically controlled theology each for its

49.For specific examples, helpful or questionable, see: Bosch (1991); Muller (1991) VanEngen (1994: chapters 3-4).

50. He (Lints 1993) further observes that: 'the Reformers held that the proper context for the interpretation of the text is not the subjective interaction between a particular passage and a particular person but rather the interaction of a given passage with the whole of Scripture itself, the essential unity of which is established by its divine origin. And determinations of this sort, they believed, are most effectively accomplished by the corporate study of the Scriptures. The question we should be seeking to answer is not 'What does this text mean to me?' but 'What does this particular biblical text mean, and how does it fit into the entirety of the biblical record?' (p. 93). 
own language, culture and generation, the enterprise cannot be too highly lauded and encouraged; and the result in each case will mesh substantially with other efforts elsewhere, once their respective 'horizons of understanding' have been fused. (p. 255; cf. also Muller 1991:220)

The new believing community is often more able and effective than foreign missionaries in contextualising the gospel and avoiding cultural sins. Hiebert (1994:101-102) outlines four steps in this process: (1) the Bible must be translated into new languages, (2) old customs must be dealt with, (3) the worship of the church should not be patterned after foreign a culture and (4) the church should apply biblical truth to the day-to-day issues it faces. Additionally, Kraft (2002:132-156) draws attention to differences between first generation theologising and that of following generations: the first generation often has a tendency to be overly critical of local culture and more open to the church planter's culture, whereas following generations tend to be more accommodating to local customs.

\section{Problems of Ecclesial Theologising}

Yet there are problems to avoid in this process. Sin always crouches at the door; every context in this world reflects a culture of suppression and distortion of the truth. As Christ observed in John 17, the world is no friend to the Truth, and yet believers are sanctified by the Truth as they live in this world. Tite Tiénou (1984:151-165) notes the problem that some theologising of non-Western churches may be guilty of reacting against the teaching of the Western church in order only to express their own identity. But even greater is the problem of syncretism.

There are at least two types of syncretism: cultural and theological. Cultural syncretism, which is more of a danger in missional contexts, is the uncritical acceptance of contaminated cultural forms, or the enforcing of foreign culture as if it were gospel truth. Hiebert explains how syncretism is the likely result of both uncritical contextualisation and a lack of contextualisation. If contextualisation uncritically accepts contaminated cultural forms, the result is a mixture of Christianity and other beliefs. If a foreign culture is enforced without contextualisation, then either the gospel is rejected along with the foreign culture, or the old culture goes underground, becoming a folk religion while the gospel or foreign culture become the high religion (Hiebert 1985:183-190). Theological syncretism takes place at the very heart of culture, Nicholls (1979) states:

... it is the joining together of concepts and images at the depths of world view and cosmology, and of moral and ethical values. It is more destructive than cultural syncretism though in fact it usually leads to cultural syncretism of the accommodation type. (p. 31) $)^{51}$

\section{Protections for Ecclesial Theologising}

How is the church protected from error as it attempts faithfully to confess the gospel in cultural context? There are 51.Nicholls (1979:28-34) gives a description of syncretism in its various forms. at least three safeguards in this process: the Scriptures, the Holy Spirit, and the covenant community.

Firstly, sola Scriptura must be affirmed and maintained. The Bible is God's Word and must remain the only infallible rule for faith and life. As William Larkin (1988) states:

It is possible for the Scriptures to serve also as a casebook, a platform for further elaboration, or as an occasion for the ongoing dynamic of truth seeking. There is place for such interpretive options as long as they remain subsidiary to the primary function of Scripture as the standard of reference. (p. 284)

Secondly, the inward testimony of the Holy Spirit not only confirms the Word and illumines the interpreter, but also guides the process of gospel communication and contextualisation, preserving believers in the Truth. The Holy Spirit's assistance in cross-cultural gospel communication has received little attention (cf. Bavinck 1956:221-246), confused by neo-orthodox views of revelation. But, as Carson (1987) notes, this is most emphatically not a surreptitious appeal to mystical and ill-defined knowledge, but an acknowledgement that the Spirit's convicting, transforming, regenerating work changes attitudes and motives and values that had once erected immense epistemological barriers (Carson 1987:256-257).

Thirdly, the church is a local and global hermeneutical community that serves to test and correct all contextual theology by the Scriptures. Hiebert (1994) and others repeatedly draw attention to this safeguard:

We need each other to see our personal biases, for we see the ways others misinterpret Scriptures before we see our own misinterpretations. Along the same line, we need Christians from other cultures, for they often see how our cultural biases have distorted our interpretations of the Scriptures. This corporate nature of the church as a community of interpretation extends not only to the church in every culture, but also to the church in all ages. (p. 91)

\section{Globalised theology: Unity with diversity}

Having considered how the cultural context should influence theological formulation, one concluding question remains: what does this look like on the global scale? Writing more than a century ago, Herman Bavinck (1894) argued in 'The future of Calvinism' (quoted in Conn 1983) that:

Calvinism wishes no cessation of progress and promotes multiformity. It feels the impulse to penetrate ever more deeply into the mysteries of salvation and in feeling this honors every gift and different calling of the Churches. It does not demand for itself the same development in America and England which it has found in Holland. This only must be insisted upon, that in each country and in every Reformed Church it should develop itself in accordance with its own nature, and should not permit itself to be supplanted by foreign ideas. (p. 18)

Why did a conservative theologian of Bavinck's calibre write this? Was he not aware of the problems already created by the 
limited indigenisation of his day? Bavinck was not aware of today's misuse and deviation of contextual theology. He was, however, attuned to the views of Schleiermacher and others who had set the course for present divergence. But more important, Bavinck was keenly aware of the unity of the Scripture and the unity of the church that transcends all historic and geographic differences. Bavinck (2003:213) built his theology on the unity of God's revelation and therefore could account for the diversity of cultural confessions. ${ }^{52}$ Globalised theology makes one confession of faith (Eph 4:4-6), united by one Spirit of Truth, gathered into one household and built on one foundation (Eph 2:11-22).

What does globalised theology look like? It is a theology informed by the insights of faithful theologians in every cultural context; 53 a symphony of different voices all contributing to a fuller expression of the unchanging Word (cf. Carson 1996:552; Poythress 1987). It is important for every cultural group to contribute to the worldwide understanding of biblical truth (Carson 1987:256). ${ }^{54}$ This will guard the church, locally and globally, as it continues 'to penetrate ever more deeply into the mysteries of salvation' (Bavinck 1894:18). Hiebert (1994) identifies the relationship of local and global theologising:

Just as believers in a local church must test their interpretations of Scriptures with their community of believers, so churches in different cultural and historical contexts must test their theologies with the international community of churches and the church down through the ages. (p. 103)

This process happens in much the same way as historical theology informs and tests contemporary formulations, though historical theology that has withstood the test of time is much more reliable than newer contributions. ${ }^{55}$

But does not contextualisation on a global scale lead to even further fragmentation? Many hesitate to allow contextualisation for fear of cultural relativism. Indeed, if the above principles are not followed or if Scripture is treated improperly, as a 'a norming norm' and not as the foundation and source of theology, then the likely results are the contradictory fragmentation produced in the last halfcentury by liberal theology and/or the mystical pseudounity of a 'Christian style' proposed by postconservative evangelicals. But if the revelatory trajectory remains a

52. Bavinck (2003) concludes: 'The Reformed person is not content with an exclusively historical stance but raises his sights to the idea, the eternal decree of God.... The Reformed church is not limited to on country and nation but has expanded into various countries and nations. That which is typically Reformed has not been laid down in a single confession but found expression in numerous confessions (p. 177)

53.Truth is not 'found' in the consensus or synthesis of particular truths. Rather, each contextual theology is an attempt to express the one Truth of God's Word.

54.Carson (1996) says: 'Instead of appealing to the principles of contextualisation to justify the assumption that every interpretation is as good as every other interpretation, we will recognise that not all of God's truth is vouchsafed to one particular interpretive community - and the result will be that we will be eager to learn from one another, to correct and to be corrected by one another, provided only that there is a principled submission to God's gracious self-disclosure in Christ and in the Scriptures' (Carson 1996:552).

55.This is especially true concerning the confessions that have been recognised by large sections of the global church. Many who advocate contextual theology do not follow their own principles when they give little attention to contributions from history. Disregard for historical contributions is both foolish and irresponsible. one-way process, while the hermeneutical spiral between text and context is allowed to bring the Spirit-guided ecclesial community ever closer to the unchanging inspired Word of God, then the result will not be cultural relativism, but rather a global theology faithful to Scripture that also speaks in each cultural context. This is the ideal; perfect contextualised theology on this side of the parousia is impossible to attain because sin affects both culture and interpreter, marring the entire process (1 Cor 13:12). But it is an ideal worth pursuing, a goal to desire, a reality that will be fully realised when our theology has been perfected ( $R v$ 7:9-10).

\section{Acknowledgements Competing interests}

The author declares that he has no financial or personal relationships which may have inappropriately influenced him in writing this article.

\section{References}

Bavinck, H., 1894, 'The future of calvinism', Presbyterian and Reformed Review 5, 17.

Bavinck, J.H., 1956, 'Introduction to missions, and the problem of adaptation and communication', International Review of Missions 45, 307-313. http://dx.doi. org/10.1111/j.1758-6631.1956.tb00849.x

Bavinck, J.H., 1960, An introduction to the science of missions, Presbyterian \& Reformed Publishers, Phillipsburg, NJ.

Bavinck, J.H., 2003, Reformed dogmatics: Prolegomena, vol. 1, transl. J. Vriend, Baker Academic, Grand Rapids, MI.

Bevans, S.B., 1985, 'Models of contextual theology', Missiology: An International Review 13, 185-202.

Bevans, S.B., 1992, Models of contextual theology, Orbis Books, Maryknoll, NY.

Bevans, S.B., 2009, An introduction to theology in global perspective, Orbis Books, Maryknoll, NY.

Bosch, D.J., 1991, Transforming mission: Paradigm shifts in theology of mission, Orbis Books, Maryknoll, NY.

Calvin, J., 1960, Institutes of the Christian religion, transl. F.L. Battles, Westminster Press, Philadelphia, PA.

Carson, D.A., 1984a, 'A sketch of the factors determining current hermeneutical debate in cross-cultural contexts', in D.A. Carson (ed.), Biblical interpretation and the church: The problem of contextualation, pp. 11-29, Nelson, New York.

Carson, D.A., 1984b, 'Current hermeneutical debate', in D.A. Carson (ed.), Biblical interpretation and the church: The problem of contextualization, pp. 19-20, Nelson, New York.

Carson, D.A., 1987, 'Church and mission: Reflections on contextualization and the third horizon', in D.A. Carson (ed.), The church in the Bible and the world: An international study, pp. 213-257, Paternoster Press, Exeter.

Carson, D.A., 1996, The gagging of God: Christianity confronts pluralism, Zondervan, Grand Rapids, MI.

Carson, D.A., 2008, Christ and culture revisited, Eerdmans, Grand Rapids, MI.

Clark, D.K., 2003, To know and love God: Method for theology, Crossway Books, Wheaton, IL.

Conn, H.M., 1983, 'The missionary task of theology: A love/hate relationship', Westminster Theological Journal 45(1), 13-14.

Conn, H.M., 1984, Eternal word and changing worlds: Theology, anthropology, and mission in trialogue, Academie Books, Grand Rapids, MI.

Conn, H.M., 1997, 'Contextual theologies: The problem of agendas', in W.R. Barr (ed.), Constructive Christian theology in the worldwide church, pp. 91-104, Eerdmans, Grand Rapids, MI.

Cortez, M., 2005a, 'Context and concept: Contextual theology and the nature of theological discourse', Westminster Theological Journal 67(1), 85-102.

Cortez, M., 2005b, 'Creation and context: A theological framework for contextual theology', Westminster Theological Journal 67(2), 347-362.

Cragg, K., 1985, Jesus and the Muslim: An exploration, Oneworld Publications, Oxford. Davis, J.J., 1984, Foundation of evangelical theology, Baker Books, Grand Rapids, MI.

Dyrness, W., 1990, Learning about theology from the Third World, Academie Books, Grand Rapids, MI.

Dyrness, W., 1992, Introduction to cross-cultural theology, Zondervan, Grand Rapids, MI.

Dyrness, W., 1994, Emerging voices in global Christian theology, Zondervan, Grand Rapids, MI. 
Fleming, B.C.E., 1980, Contextualization of theology: An evangelical assessment, William Carey Library, Pasadena, CA.

Gadamer, H-G., 1976, Philosophical hermeneutics, University of California, Berkley, CA.

Gilliland, D., 2000, 'Contextualization', in A. Moreau (ed.), Evangelical dictionary of world mission, pp. 225-227, Baker Books, Grand Rapids, MI.

Greeson, K., n.d., Camel training manual, International Mission Board, s.l.

Grenz, S.J. \& Franke, J.R., 2001, Beyond foundationalism: Shaping theology in a postmodern context, Westminster John Knox, Louisville, KY.

Guder, D.L. (ed.), 1998, Missional church: A vision for the sending of the church in North America, Eerdmans, Grand Rapids, MI.

Guder, D.L., 2000, The continuing conversion of the church, Eerdmans, Grand Rapids, MI.

Healey, J. \& Sybertz, D., 1996, Towards an African narrative theology, Orbis Books, Maryknoll, NY

Hesselgrave, D.J., 1984, 'Contextualization and revelational epistemology', in E.D. Radmacher \& R.D. Preus (eds.), Hermeneutics, inerrancy, \& the Bible, pp. 691-738, Academie Books, Grand Rapids, Ml.

Hesselgrave, D.J., 1994, Scripture and strategy: The use of the Bible in postmodern church and mission, William Carey Library, Pasadena, CA.

Hesselgrave, D.J., 1999, 'Christian contextualization and biblical theology', in D.W. Kennard (ed.), The relationship between epistemology, hermeneutics, biblical theology and contextualization, pp. 153-180, Edwin Mellen Press, Lewiston, NY.

Hesselgrave, D.J., 2001, 'Contextualization of theology', in W.A. Elwell (ed.), Evangelical dictionary of theology, pp. 294-295, Baker Academic, Grand Rapids, MI.

Hesselgrave, D.J. \& Rommen, E., 1989, Contextualization: Meanings, methods, and models, Baker Books, Grand Rapids, MI.

Hiebert, P.G., 1973, 'Cultural relativism and theological absolutes', Direction 2(1), 2-6.

Hiebert, P.G., 1985, Anthropological insights for missionaries, Baker Books, Grand Rapids, MI.

Hiebert, P.G., 1987, 'Critical contextualization', International Bulletin of Missionary Research 11(3), 104-111. http://dx.doi.org/10.1177/239693938701100302

Hiebert, P.G., 1994, Anthropological reflections on missiological issues, Baker Books, Grand Rapids, MI

Hiebert, P.G., 1996, 'The social sciences and missions: Applying the message', in E. Rommen \& G. Corwin (eds.), Missiology and the social sciences: Contributions, cautions and conclusions, pp. 184-213, William Carey Library, Pasadena, CA.

Hiebert, P.G. \& Tiénou, T., 2002, 'Missions and the doing of theology', in M. Ortiz \& S.S. Baker (eds.), The urban face of missions: Ministering the gospel in a diverse and changing world, pp. 85-96, P\&R Publishing, Phillipsburg, NJ.

Horton, M.S., 2002, Covenant and eschatology: The divine drama, Westminster John Knox, Louisville, KY.

Hunsberger, G.R. \& VanGelder, C. (eds.), 1996, The church between gospel and culture The emerging mission in North America, Eerdmans, Grand Rapids, MI.

Ingraffia, B.D., 1995, Postmodern theory and biblical theology, Cambridge University Press, New York.

Kraft, C., 1996, Anthropology for Christian witness, Orbis Books, Maryknoll, NY. (Kraft Christianity and culture.)

Kraft, C.H., 2002, 'Generational appropriateness in contextualization', in M. Ortiz \& S.S. Baker (eds.), The urban face of missions: Ministering the gospel in a diverse and changing world, pp. 132-156, P\&R Publishing, Phillipsburg, NJ.

Kraft, C.H., 2005, Christianity and culture: A study in biblical theologizing in cross cultural perspective, rev. edn., Orbis Books, Maryknoll, NY.

Larkin, W.J., Jr., 1988, Culture and biblical hermeneutics: Interpreting and applying the authoritative word in a relativistic age, Baker Books, Grand Rapids, MI.

Lingenfelter, S., 1998, Transforming culture: A challenge for Christian mission, 2nd edn., Baker Books, Grand Rapids, MI.

Lints, R., 1993, The fabric of theology: A prolegomenon to evangelical theology, Eerdmans, Grand Rapids, MI.

Moreau, A.S., 2006a, Contextualization articles and annotations by section as of 8/17/2005, viewed 05 October 2006, from http://www.wheaton.edu/intr/ Moreau/532/home.htm
Moreau, A.S., 2006b, 'Contextualization: Course notes', viewed 05 October 2006, from http://www.wheaton.edu/intr/Moreau/532/532.pdf

Moreau, A.S., 2006c, 'Contextualization that is comprehensive', Missiology 34(3), 325-335.

Moreau, A.S., 2012, Contextualization in world missions: Mapping and assessing evangelical models, Kregal Publications, Grand Rapids, MI.

Muller, R.A., 1991, The study of theology: From biblical interpretation to contemporary formulation, Zondervan, Grand Rapids, MI.

Nevius, J.L., 1892, Demon possession and allied themes, F.H. Revell, Chicago, IL.

Newbigin, L., 1986, Foolishness to the Greeks: The gospel and western culture, Eerdmans, Grand Rapids, MI.

Nicholls, B.J., 1979, Contextualization: A theology of gospel and culture, InterVarsity, Downers Grove, IL.

Nida, E.A., 1954, Customs and cultures, Harper \& Row, New York.

Nida, E.A., 1964, Toward a science of translating, with special reference to principles and procedures involved in Bible translating, Brill, Leiden.

Niebuhr, H.R., 1951, Christ and culture, Harper \& Row, New York.

Orobator, A.E., 2008, Theology brewed in an African pot, Orbis Books, Maryknoll, NY.

Packer, J.I., 1983, 'Infallible Scripture and the role of hermeneutics', in D.A. Carson \& J.D. Woodbridge (eds.), Scripture and truth, pp. 349-349, Zondervan, Grand Rapids, MI.

Poythress, V.S., 1987, Symphonic theology: The validity of multiple perspectives in theology, P\&R Publishing, Phillipsburg, NJ.

Schreiner, L., 1976, 'Contextual theology', in E. Fahlbusch (ed.), The Encyclopedia of Christianity, pp. 678-679, Eerdmans, Grand Rapids, MI.

Schreiter, R.J., 1985, Constructing local theologies, Orbis Books, Maryknoll, NY.

Stott, J.R.W. \& Coote, R., 1980, Down to earth: Studies in Christianity and culture, Eerdmans, Grand Rapids, MI.

Taber, C.R., 1979, 'Contextualization: Indigenization and/or transformation', in D. McCurry (ed.), The gospel and Islam: A 1978 compendium, pp. 143-150, MARC Monrovia, CA.

Tiénou, T., 1984, 'The church in African theology: Description and analysis of hermeneutical presuppositions', in D.A. Carson (ed.), Biblical interpretation and the church: The problem of contextualization, pp. 151-165, Thomas Nelson, the church:

Tiénou, T. \& Hiebert, P.G., 2006, 'Missional theology', Missiology 34(2), 219-238.

Turaki, Y., 2012, The trinity of $\sin$, HippoBooks, Nairobi.

VanEngen, C., 1994, Mission on the way: Issues in mission theology, Baker Books, Grand Rapids, MI.

Vanhoozer, K.J., 2005, The drama of doctrine: A canonical linguistic approach to Christian theology, Westminster John Knox, Louisville, KY.

VanTil, H.R., 1959, The calvinistic concept of culture, Baker Academic, Grand Rapids, MI.

Von Allmen, D., 1975, 'The birth of theology: Contextualization as the dynamic element in the formation of New Testament theology', International Review of Mission 64, 37-52. http://dx.doi.org/10.1111/j.1758-6631.1975.tb01155.x

Walls, A.F., 1996, The missionary movement in Christian history: Studies in the transmission of the faith, Orbis Books, Maryknoll, NY.

Wan, E., 2003, 'Critiquing the method of traditional western theology and calling for sino-theology', Global Missiology, October, viewed 24 November 2006, from http://www.globalmissiology.net

Wan, E., 2004, 'Ethnohermeneutics: Its necessity and difficulty for all Christians of all times', Global Missiology, January, viewed 24 November 2006, from http://www. globalmissiology.net

Wells, D.F., 1985, 'The nature and function of theology', in R.K. Johnston (ed.), The use of the Bible in theology: Evangelical options, p. 177, John Knox, Atlanta, GA.

Wellum, S.J., 2004, 'Postconservatism, biblical authority, and recent proposals for redoing evangelical theology: A critical analysis', in M.J. Erickson, P.K. Helseth \& J. Taylor (eds.), Reclaiming the center: Confronting evangelical accommodation in postmodern times, pp. 161-197, Crossway Books, Wheaton, IL. 